\title{
The Audience Habit of Media Consumption in The Transition of Digitalization Broadcasting in Central Java
}

\author{
Made Dwi Adnjani \\ Communication Studies Department \\ Language and Communication Faculty \\ Universitas Islam Sultan Agung (UNISSULA) \\ Central Java, Indonesia. \\ made@unissula.ac.id
}

\author{
Mubarok \\ Communication Studies Department \\ Language and Communication Faculty \\ Universitas Islam Sultan Agung (UNISSULA) \\ Central Java, Indonesia. \\ mubarok@unissula.ac.id
}

\begin{abstract}
Indonesia already has a digital TV migration roadmap based on studies and consultations with broadcasters. The Government has established DVB-T technology as a standard of free terrestrial digital television broadcasting through Ministerial Regulation of Kominfo No: 07 / P / M.KOMINFO / 3/2007. If the roadmap of analog to digital migration goes according to the plan, starting in April 2012 has begun a DVB-T2 digital TV broadcast trial in several big cities. The next roadmap is simulcast or simultaneous broadcasts between analog and digital nationwide until 2014 , then gradually cessation of analog systems in some places until 2017, and total analog switches off by 2018. Migration digital broadcasting in Indonesia cannot be separated from the problems that occur such as technology transfer process, political economy issues that led to the judicial review, until the socialization is not maximized and the last problem also concerns from academics related to the draft revision of the Broadcasting Law. It is important to see how the audience habit of media consumption in Central Java and how the perception of Central Javanese society towards analogto-digital broadcasting migration policy. This research was conducted by focusing on the audience habit and the perception of digitalization broadcasting migration policy using the type of descriptive qualitative research. In depth interview is done towards informants scattered in four cities in Central Java, namely Semarang, Purwokerto, Magelang and Pekalongan. As a qualitative study, the finding will be analyzed using data reduction and data interpretation. It is done to gain the deep understanding towards the words and attitude of the informants by showing the concept and theory explaining the research result. The results showed that the majority of people in Central Java were not aware of the broadcasting digitalization policy and there isn't changing habit for media consumption.
\end{abstract}

Keywords—media consumption; digitalization; broadcasting

\section{INTRODUCTION}

The presence of technology should provide great benefits to all human beings. Many technological presences do not match the needs of its users so it often causes problems rather than provides benefits. Similarly with analog to digital broadcast migration policy, this technology transfer policy is not basically just a technology transfer but also a change of mindset to the various aspects that will emerge from this digital technology. It is therefore important for the governments to engage intensive socialization in order the communities as owners of the frequency can understand digital technology, understand the steps that need to be taken to enjoy and receive digital broadcasts, because the consequences go for those who still use analog television, they must purchase additional tools to receive digital broadcasts, as well as to make people understand that in a given time analog broadcasting will be stopped so the society as a public of the broadcasting system is not harmed.

The emerged of internet era makes changes to the media consumption pattern. The change is faster delivery of news that have no bounds. On the other hand, the development of print media has decreased caused by the shift in consumer consumption patterns from print media to the internet media as a means of getting more actual news and information. The society's different education levels will indirectly affect the selection of information quality and selection of appropriate media types to meet the information needs. It happens because the reader or viewer will be more dependent on media information to meet certain needs and achieve certain goals, as explained by Ball- Rokeach and DeFleur (in [1, p. 428]).

There is problem of giving lack of socialization provided by the government on the policy of analog to digital broadcast migration because some parties refuse to precede the implementation of this policy. It is caused by the revision of Broadcasting Act no. 32 year 2002 has not been done so far. Based on this phenomenon, this research is conducted to find the shift of consumption pattern and this research aims to (1) map the audience habit to find the change pattern of shifting media consumption pattern, and (2) to know the perception of Central Java people about the migration of analog to digital broadcasting so that the government is expected to develop creative strategy to socialize broadcast migration effectively.

\section{THE CONCEPTS OF Audience HABIT}

Audience habit is a habit pattern utilizing media explained by the frequency a person consumes media. The study of news consumption is the study of media in audiences, where the meaning of the audience is actually a collection of 
communication content recipients as a part of the communication process cycle. McQuail [2] makes a typology describing the diversity of audiences definition including audiences as assemblies, audiences as people who are targeted by communication content delivered by communicators, audiences as an event or incident or "happening" describing the experience of receiving a message either alone or when they share with others as an interactive event in everyday life, and the last, audience as a listener or an audition.

In addition, Sulivan, as quoted from James G. Webster, suggests three models of media audiences, namely audience as outcomes, audiences as a mass, and audiences as agents. Audience model as an outcome views that the audience is the people who are being exposed by the media, where the discussion in this concept is paying attention to the power of media to form influences that can determine individual life and its implications on society as a whole. The second concept is audience as a mass. Audiences are perceived as a group of people who are widespread across space and time which are directly autonomous and interconnected with one another only a few know or do not know each other. The third concept is audiences as agents. Audiences are free to choose what will be consumed from the media. With the self-ability to make interpretations, they make their own meaning and they use media considered as the most appropriate for them. This study uses audience as an agent in which will be examined his behavior in consuming news. Audience position in the communication process is the party who received the communication content. This study is using the concept of consumers who consume the contents of communication.

The concept of consumption is one of the communication process elements used by Hall which criticizes the linear communication model, sender-mesage-reciever. Hall stated that the model does not reveal the complexity between stages or moment. Hall suggests production, circulation, distribution / consumption and reproduction models. Consumption, according to Hall, is the stage where the communicant is facing the decoding process of messages encoded by communicators. For Hall, decoding done by the communicant is not always related or associated with encoding. In this consumption study, it does not focus on the meaning of the news as stated by Hall, but it focuses on the pattern of society in consuming news, as Newhagen stated it is an access that includes the dimensions access to technology and access to content.

\section{RESEARCH METHODS}

In order to achieve the purpose of this research, this research design is a qualitative research. The research is conducted by in-depth interview technique, which contains the objectives and main questions asked. The materials proposed are based on a conceptual framework including the habit of using information resources, accessed information, and media consuming habits. Researchers conducted interviews to informants scattered in four cities namely Semarang, Magelang, Purwokerto and Pekalongan. The four cities were chosen with several considerations: representing Central Java in the south, north, west and east. In addition, the four cities are also included in the socialization of digitalization pilot plan. The researcher also conducted an interview with the Indonesian Broadcasting Commission of Central Java functionaries to get an overview of the process of socializing analog to digital migration in Central Java. Researchers also conducted field observations by following some discussions about the migration process held by students. Data analysis is done by data reduction and data interpretation.

\section{RESEARCH RESUltS AND DisCUSSIONS}

This study does not define demographic characteristics because television viewers in Central Java do not have special segmentation. Precisely through the results of this study, the information gained that generally television viewers in Central Java is male. The results also indicate that informants spread across four cities in Central Java were between 20-30 years old mostly in Semarang, some others were over 55 years old in Magelang and Pekalongan and most of them were retired. Meanwhile, their job are varies like civil servants, entrepreneurs, university students, students, lecturers, traders, honorary teacher and even housewives. The level of education also varies because it also shows a person's ability to understand the message, using the media as well as related to the way, the habit of using the media. The majority of informants are senior high school graduates (Semarang, Magelang, Purwokerto), while in Pekalongan, the majority informant are junior high school graduates.

Television is the most accessed media by informants in the last 1 month. The low cost, easy and varied content makes television as much-loved media. On the other hand, social media is the main choice of informants because of its more private and interactive. Interestingly, it was only in the Semarang who still consumes magazines as a source of information. Television becomes a media that is considered as easy to be accessed both related to its existence and the cost to access. In every home, there are televisions that make it easy to access and mostly they spend more than 4 hours a day watching television. Television is mostly accessed in prime time between 4 pm-9 pm. However, there are informants who consider that the main time to watch television is exactly in the morning because the content presented fits his needs.

Social media is an option to be consumed because it has a high mobility capability that can be accessed everywhere as long as there is internet access and electricity. Social media becomes a medium that is ready to be accessed within 24 hours according to the needs of its users. Its flexibility and high mobility make social media accessible in long span of time.

Home became a favorite place to access television, while social media can be accessed everywhere. Radio accessed within a certain time and adjusted the presence of radio devices around the informant like when they are driving. Newspapers and magazines are widely accessed in the workplace, regarding the availability of such media in the office especially for those who are not subscribed. 
Social media users are accustomed to using various social media simultaneously. At the same time they access Whatsapp, BBM, Line, Twitter, Facebook via the same device. While the use of one media is when they access television, read newspapers or magazines and listen to the radio. Although they do not access other media but they still do other activities such as chatting with fellow television viewers. In Semarang, online media became the reference of respondents to obtain information on the progress of technology in the field of information. While in other cities, they still put television as the main media to access information. Print media is selected to gain a depth discussion about the new information technology.

The majority of informants said they did not know about the migration of analogue broadcasting to digital broadcasting. People do not know about the migration plan because of the absence of certainty towards the implementation of migration and the absence of massive and planned socialization. Those who know the migration process are young informants who are generally University student. As for the community in some areas, the migration process is considered as not too important so they do not care about that. Socialization must be done to make people understand. They should know the advantages and the disadvantages of the migration process, and the reason why migration should be done. People also see the importance of socialization related to what rights and obligations they will receive when the migration process done. They also do not know if the government's policy to do analog switch off is really done, for those who still use analog television, then the TV cannot be used again unless it is using set top box. Things like this need to be understood in order people will not feel harmed.
Digital broadcasting does provide an enormous opportunity for the broadcast industry, such as more channels, interactive broadcast provision, and the content of creative programs can be developed. However, there are two factors to considered; the first is analog television will be shut down, thus people without digital equipment will not be able to receive broadcasts; the second is during the transition period of analog to digital broadcasting, will they, the people with visual impairments or blind people, get the same opportunity to access the broadcast or it will be limited later? It should be a matter for discussion.

\section{ACKNOWLEDGMENT}

Thanks to the Directorate of Research and Community Service, the Directorate General for Research and Development of the Ministry of Research, Technology and Higher Education who has funded this research through the National Strategic Research Institution 2018. Great thanks also to the of Communication Studies department FBIK Unissula, LPPM Unissula Semarang, KPID Central Java and Jaringan Pegiat Literasi Digital (Japelidi) Semarang who help conducting this research.

\section{REFERENCES}

[1] S. Littlejohn and K. A. Foss, Teori komunikasi [Theories of human communication]. Salemba Humanika. 2010.

[2] D. McQuail, Mass Communication Theory, 6th ed. London: Sage Publication, 2010. 